Original Research Paper

\title{
Effects of Potassium Fulvic Acid and DA-6 on the Growth and Yield of Tomato Cultivated with Rock Wool
}

\author{
${ }^{1}$ Xiao Huaijuan, ${ }^{1,2}$ Zhou Yan, ${ }^{1}$ Mao Ke, ${ }^{1}$ Wang Jiqing and ${ }^{1}$ Liu Ke \\ ${ }^{1}$ College of Horticulture, Henan Agricultural University, Zhengzhou, 450002, China \\ ${ }^{2}$ Institute of Tropical Agriculture and Forestry, Hainan University, Haikou, 570228, China
}

\author{
Article history \\ Received: $13-02-2020$ \\ Revised: 14-03-2020 \\ Accepted: 06-04-2020 \\ Corresponding Author: \\ Wang Jiqing \\ College of Horticulture, Henan \\ Agricultural University, \\ Zhengzhou, 450002, China \\ Email:wjq16@sina.com
}

\begin{abstract}
Potassium fulvic acid and diethyl aminoethyl hexanoate (DA-6) are two kinds of growth regulators with yield increasing and quality improving. There are few reports on the effects of adding potassium fulvic acid and DA-6 in nutrient solution on the growth of soilless culture of vegetables. In this study, tomato was used as the test material to add different concentrations of potassium fulvic acid $\left(0,15,30 \mathrm{mg} \cdot \mathrm{L}^{-1}\right)$ and DA-6 $(0,2.5$, $\left.5 \mathrm{mg} \cdot \mathrm{L}^{-1}\right)$ into nutrient solution of total nutrient minerals, so as to study the effects of adding two growth-regulating substances to nutrient solution of total nutrient mineral on the growth, yield and quality of tomato in soilless cultivation with rock wool in solar greenhouse. The results showed that: With no addition of potassium fulvic acid and DA-6 as the control, in the early stage of bearing fruit, the potassium fulvic acid added with $30 \mathrm{mg} \cdot \mathrm{L}^{-1}$ nutrient solution alone had an inhibitory effect on tomato plant height and the inhibition could be alleviated by adding DA-6. When $30 \mathrm{mg} \cdot \mathrm{L}^{-1}$ potassium fulvic acid and DA-6 were added together, the fresh quality of single stem and dry quality of single leaf in the early and middle stage of tomato bearing fruit were significantly improved. $15 \mathrm{mg} \cdot \mathrm{L}^{-1}$ potassium fulvic acid and $2.5 \mathrm{mg} \cdot \mathrm{L}^{-1} \mathrm{DA}-6$ had the best effect on the total yield of a single plant, which was $21.77 \%$ higher than that of the control. $15 \mathrm{mg} \cdot \mathrm{L}^{-1}$ potassium fulvic acid and DA-6 could significantly increase the C content and sugar acid ratio of tomato fruit. To summarize, $15 \mathrm{mg} \cdot \mathrm{L}^{-1}$ potassium fulvic acid and $2.5 \mathrm{mg} \cdot \mathrm{L}^{-1}$ DA-6 showed synergistic effect, which has the best improvement effect on the growth, yield and quality of best.
\end{abstract}

Keywords: Potassium Fulvic Acid, Diethyl Aminoethyl Hexanoate, Tomato, Nutrient Solution

\section{Introduction}

Fulvic acid is a plant growth regulator extracted from natural humus, which can dissolve in acid, alkali and water. Its molecular weight is small and is easy to be absorbed by plants with high chemical activity and biological activity. It is widely used in agriculture and has good effect (Stevenson, 1994; Justi et al., 2019). Fulvic acid has the characteristics of increasing fertilizer utilization, improving soil physical and chemical properties, promoting crop growth and improving drought resistance, which has been widely used in wheat, cabbage, peanut and achieved good results (Baigorri et al., 2009; Canellas et al., 2015; De Pascale et al., 2017). For instance, Xiao et al. (2004) found that Composite systems of surfactants and fulvic acid could significantly improve B and Mn uptake of cabbage and peanut leaf.
Liu et al. (2019) reported that the number of bacteria, fungi and actinomycetes in soil increased significantly by the use of fulvic acid fertilizerand finally reached the maximum when the application amount was $6 \mathrm{~g} / \mathrm{kg}$. The activity of four soil enzymes was promoted by fulvic acid fertilizer, especially for that of catalase, which showed the most significant promoting effect.

Diethyl aminoethyl hexanote, also known as DA-6, is a plant growth regulator discovered by American scientists in the 1990s (Nkansah et al., 2018; Moayedi et al., 2019). It can promote the germination of plant seeds and growth of seedlings, improve the photosynthetic performance of crops and improve the quality of crops (Xu et al. 1995; Li et al. 2000). DA-6 can also improve the regeneration rate of tissue culture, accelerate the growth of adventitious buds, promote the growth of Chlorella and increase the content of fatty acids and also enhance the 
stress resistance and salt tolerance of plants (Chen et al., 2013; Li et al., 2018; Chzhu et al., 2020). For example, Jiang et al. (2015) investigated that DA-6 accelerated the microalgae growth and simultaneously improved the quality and quantity of lipid for biodiesel production. Zhang et al. (2014) confirmed that the mixture of ethephon and diethyl aminoethyl hexanoate (DA-6) could improve lodging resistance and yield in maize.In addition, a mixture of DA-6 and indole-3-acetic acid could promote the growth and fatty acid content of some microalgae for biodiesel production (Salama et al., 2017).

Most of the existing researches are limited to the soil cultivation mode and few of them have been reported in the application of soilless cultivation nutrition. Solar greenhouse is the main facility for fruit and vegetable cultivation in Huang Huai Region. Since the great changes of environmental conditions in early spring and summer may affects the soil cultivation of fruits and vegetables, especially the soilless cultivation, this study was aimed at researching the effects of potassium fulvic acid and DA-6 added to soilless culture nutrient solution on the growth, yield and quality of rock cotton tomato, in order to explore the feasibility of convenient application of these two growth regulators in soilless culture in the solar greenhouse.

\section{Experimental Materials and Methods}

\section{Experimental Material}

The tomato variety used in the experiment was "Shuangkang 38", which was cultivated by Henan Agricultural Vocational and technical college. The size of rock wool block used for tomato seedling is $10 \times 10 \times 5$ $\mathrm{cm}$; the specification of rock wool bag for tomato cultivation is $100 \times 25 \times 7 \mathrm{~cm}$ and the density of rock wool block for seedling and bag for cultivation is $110 \mathrm{~kg} \cdot \mathrm{m}^{-3}$. It is made of hydrophilic rock wool board produced by Zhengzhou Datang refractory and thermal insulation material Co., Ltd. Potassium fulvic acid with purity $\geqq$ $30.0 \%$ is produced by Xinjiang Shuanglong Humic Acid Co. Ltd. DA-6 with purity $\geqq 98 \%$ is produced by Zhengzhou Zhengshi chemical products Co., Ltd. The formula of basic nutrient solution used in the experiment was: Calcium nitrate tetrahydrate $565 \mathrm{mg} \cdot \mathrm{L}^{-1}$, potassium nitrate $779 \mathrm{mg} \cdot \mathrm{L}^{-1}$, Potassium Phosphate Monobasic 409 $\mathrm{mg} \cdot \mathrm{L}^{-1}$, Ammonium dihydrogen phosphate $40 \mathrm{mg} \cdot \mathrm{L}^{-1}$, Urea $40 \mathrm{mg} \cdot \mathrm{L}^{-1}$, magnesium sulfate $359 \mathrm{mg} \cdot \mathrm{L}^{-1}$ and phosphoric acid (content $85 \%$ ) $0.203 \mathrm{ml} \cdot \mathrm{L}^{-1}$. A large number of elements are agricultural grade purity and trace elements are chemical purity.

The type of nutrient solution water pump used in the test is DB-3000, voltage $220-240 \mathrm{~V}$, power $60 \mathrm{~W}$ and the maximum water output $2500 \mathrm{~L} \cdot \mathrm{h}^{-1}$, which is manufactured by Jinlijia Mechanical and Electrical Co., Ltd. Microcomputer time control switch type is KG316T, manufactured by Delixi Group Co., Ltd.
Table 1: Concentration and number of experimental treatment

\begin{tabular}{lll}
\hline Treatment & $\begin{array}{l}\text { Potassium fulvic } \\
\text { acid } / \mathrm{mg} \cdot \mathrm{L}^{-1}\end{array}$ & $\mathrm{DA}-6 / \mathrm{mg} \cdot \mathrm{L}^{-1}$ \\
\hline $\mathrm{M}_{0} \mathrm{D}_{0}$ (Control) & 0 & 0 \\
$\mathrm{M}_{0} \mathrm{D}_{2.5}$ & 0 & 2.5 \\
$\mathrm{M}_{0} \mathrm{D}_{5}$ & 0 & 5 \\
$\mathrm{M}_{15} \mathrm{D}_{0}$ & 15 & 0 \\
$\mathrm{M}_{15} \mathrm{D}_{2.5}$ & 15 & 2.5 \\
$\mathrm{M}_{15} \mathrm{D}_{5}$ & 15 & 5 \\
$\mathrm{M}_{30} \mathrm{D}_{0}$ & 30 & 0 \\
$\mathrm{M}_{30} \mathrm{D}_{2.5}$ & 30 & 2.5 \\
$\mathrm{M}_{30} \mathrm{D}_{5}$ & 30 & 5 \\
\hline
\end{tabular}

\section{Experimental Design}

In this experiment, potassium fulvic acid and DA-6 were added to the basic nutrient solution with three levels of content respectively, nine treatments in all. Complete randomized block test design was adopted. Each community was made up of 8 rock wool bags, $1.7 \mathrm{~m}$ row space between rock cotton cultivation bags, $13.6 \mathrm{~m}^{2}$ plot areas and repeated three times. The concentration and code used for treatment are shown in Table 1.

\section{Experimental Method}

The test site is located at No.3 solar greenhouse, Maozhuang science and education experimental Park, Henan Agricultural University, at $34^{\circ} 16^{\prime} \mathrm{n}$ and $113^{\circ} 30^{\prime} \mathrm{E}$. On September 15, 2015, tomato was seeded in vermiculite matrix after germination. When it grew to "two leaves and one heart", it was seeded to rock wool block for seedling and then cultured in nutrient liquid film cultivation tank. On October 30, 2015, when the root system of the seedlings extended to the bottom of the rock wool block, they were planted in rock wool bags with a cultivation density of 4 plants $\cdot \mathrm{bag}^{-1}$, that is, 32 seedlings were cultivated in each plot. Each treatment used $150 \mathrm{~L}$ plastic bucket to contain nutrient solution, equipped with a water pump for liquid supply. The whole test used a timer to control the water pump. The solution supply system of rock cotton cultivation refers to the method of $\mathrm{Xu}$ et al. That is, the nutrient solution is not supplied in the first week after planting; the solution is supplied twice a day before flowering and fruit setting and four times a day after flowering (Xu et al., 1995). The amount of liquid supplied per day depends on the size of tomato plants and weather conditions. In sunny days, the liquid supply increased from $80 \mathrm{ml} \cdot \mathrm{D}^{-1} \cdot \mathrm{strain}^{-1}$ to $1500 \mathrm{ml} \cdot \mathrm{D}^{-1} \cdot \mathrm{strain}^{-1}$ with the growth of plants. In cloudy days, the liquid supply is reduced by $30 \%$ and in cloudy days by $50 \%$. $130 \%$ liquid supply is carried out once a week to prevent salt accumulation. The EC Value of nutrient solution was $1.8 \mathrm{~ms} \cdot \mathrm{cm}^{-1}$ from planting to fruit setting; $2.2 \mathrm{~ms} \cdot \mathrm{cm}^{-1}$ from fruit to harvest and 2.5 $\mathrm{ms} \cdot \mathrm{cm}^{-1}$ from harvest to seedlings. The $\mathrm{pH}$ of nutrient solution was maintained at 5.5-6.5. The environmental 
temperature of greenhouse is the same as that of soil cultivation in daytime and $1-2^{\circ} \mathrm{C}$ higher than that of soil cultivation in nighttime. Tomato was pruned with single vine and 6 ears of fruit were picked. Other management is the same as common soil cultivation.

Five plants were randomly selected from each plot on March 12, 2015 (early stage of fruit bearing), April 25 (middle stage of fruit bearing) and June 19, 2015 (late stage of fruit bearing) respectively to determine the plant height and stem diameter of tomato. Three plants were randomly selected from each plot on March 12, April 25 and June 19, 2015 separately to determine the fresh and dry quality of the stems and leaves of the aboveground tomatoes. Different inflorescences of tomatoes were harvested in batches when they were mature. The yield before April 28 was recorded as early yield. The yield from April 29 to May 28 was recorded as middle-term yield of the result. The yield from May 29 to June 17 is recorded as the later yield of the result. On April 28, the quality of fruit was measured at the third harvest.

\section{Measurement Items and Methods}

Tomato plant height (from stem base to plant growth point) was measured with millimeter scale (unit: $\mathrm{cm}$ ). The dry and fresh weight of plant stems and leaves were measured with analytical balance: After weighing the fresh weight with balance, green removing for $15 \mathrm{~min}$ at $105^{\circ} \mathrm{C}$ and dried at $85^{\circ} \mathrm{C}$ until the constant weight for weighing dry mass. Fruit harvest is calculated by single plant yield (unit: g). The content of organic acid in fruit was determined by $\mathrm{NaOH}$ titration. The formula was: total acidity $=\left\{\left(\mathrm{V}_{1} * \mathrm{~V} * \mathrm{~N} * \mathrm{~K} * \mathrm{a}\right) /\left(\mathrm{V}_{2} * \mathrm{~W}\right)\right\} * 100 \%(\mathrm{~V} 1$ was the total volume of sample extract (ML). V2 is the volume of filtrate from titration stone lock (ML); $\mathrm{V}$ is the volume of $\mathrm{NaOH}$ standard solution consumed in titration (ML). $\mathrm{N}$ is the concentration of $\mathrm{NaOH}$ standard solution $\left(\mathrm{mol} * \mathrm{~L}^{-1}\right) . \mathrm{K}$ is the coefficient for converting total acid to specific organic acid: Malic acid 0.067 , citric acid 0.064 , tartaric acid 0.075 , lactic acid 0.090 , oxalic acid 0.045 . A is the dilution ratio; $\mathrm{W}$ is Fresh weight of sample (g)). Molybdenum blue colorimetry was used for vitamin $\mathrm{C}$ calculation and the calculation formula is Vitamin $\mathrm{C}$ content $(\mathrm{mg} / \mathrm{g})=$ $\left.\left\{\left(\mathrm{V}_{\mathrm{A}}-\mathrm{V}_{\mathrm{B}}\right) * \mathrm{C} * \mathrm{~T}\right\} /(\mathrm{D} * \mathrm{~W})\right\} * 100 \%$ (VA is the average milliliter of fuel for titration sample $(\mathrm{ml})$; $\mathrm{VB}$ is the average milliliter of dye for titration blank control(ml); C is the total milliliter of sample extraction solution $(\mathrm{ml}) ; \mathrm{D}$ is the milliliter of sample extraction solution for titration $(\mathrm{ml}) ; \mathrm{T}$ is the milligram( $\mathrm{mg}$ ) of ascorbic acid that can be oxidized by $1 \mathrm{ml}$ of dye; $\mathrm{W}$ is the weight of sample to be tested $(\mathrm{g}))$. The content of soluble sugar was determined by anthrone colorimetry and the calculation formula is $\mathrm{C}=\mathrm{A}^{*} \mathrm{~N} / \mathrm{W}$ ( $\mathrm{C}$ is the soluble sugar content of the sample $\left(\mathrm{mg} \cdot \mathrm{g}^{-1}\right)$; $\mathrm{A}$ is the amount of soluble sugar obtained in the standard curve (ug); $\mathrm{N}$ is the dilution ratio; $\mathrm{W}$ is the weight of the sample $(\mathrm{g})$ ). Specific methods refer to the method of Li et al. (2000).

\section{Statistical Analysis}

SPSS20.0 software was used for data statistical analysis and LSD test was used for multiple comparison of significance analysis $(\mathrm{P}<0.05)$.

\section{Results}

\section{Effects of Potassium Fulvic Acid and DA-6 on plant Height and Stem Diameter of Tomato}

According to Table 2, there is no significant difference among $\mathrm{M}_{30} \mathrm{D}_{0}, \mathrm{M}_{15} \mathrm{D}_{5}$ and $\mathrm{M}_{30} \mathrm{D}_{2.5}$ on March 12, which were significantly lower than $\mathrm{M}_{0} \mathrm{D}_{0}$ and other treatments. There was no significant difference between different treatments on April 25 or June 19. The results showed that the nutrient solution adding $30 \mathrm{mg} \cdot \mathrm{L}^{-1}$ potassium fulvic acid alone had an inhibitory effect on tomato plant height in the early stage of fruit bearing and the addition of DA-6 could alleviate the inhibitory effect.

\section{The Effect of Potassium Fulvic Acid and DA-6 on the Quality of Tomato Stem and Fresh Leaves}

It can be seen from Table 3 that, compared with the control, each treatment has no significant effect on the fresh weigt of stems in the early and later stage of the result as well as the quality of stems in the whole fruit bearing period. Only in the middle of the fruit bearing, the fresh weight of $\mathrm{M}_{15} \mathrm{D}_{0}, \mathrm{M}_{30} \mathrm{D}_{2.5}$ and $\mathrm{M}_{30} \mathrm{D}_{5}$ were significantly higher than that of $\mathrm{M}_{0} \mathrm{D}_{0}$. It can be seen from Table 4 that, compared with the control, the single or combined addition of potassium fulvic acid and DA-6 has no significant effect on the quality of fresh leaves in the whole fruit bearing period. It can be seen from the early period of fruits, except $\mathrm{M}_{0} \mathrm{D}_{2.5}$, the dry weight of the other treatments was significantly higher than that of the control. In the middle stage of the fruit bearing, the leaves dry weight of $\mathrm{M}_{15} \mathrm{D}_{2.5}$ and $\mathrm{M}_{30} \mathrm{D}_{5}$ was significantly higher than that of the control. There was no significant difference in the later treatments. The results showed that the fresh quality of single plant stem in the middle stage of fruit bearing could be significantly improved by adding low concentration of potassium fulvic acid $\left(15 \mathrm{mg} \cdot \mathrm{L}^{-1}\right)$ or high concentration of potassium fulvic acid $\left(330 \mathrm{mg} \cdot \mathrm{L}^{-1}\right)$ as well as DA-6 in nutrient solution alone. The combination of potassium fulvic acid and $\mathrm{DA}^{-6}\left(15 \mathrm{mg} \cdot \mathrm{L}^{-1}\right.$ and $2.5 \mathrm{mg} \cdot \mathrm{L}^{-1}, 30$ $\mathrm{mg} \cdot \mathrm{L}^{-1}$ and $5 \mathrm{mg} \cdot \mathrm{L}^{-1}$ ) significantly improved the dry quality of single leaf in the early and middle stage of tomato fruit bearing. 
Table 2: Effects of potassium fulvic acid and DA-6 on plant height of tomatoes

\begin{tabular}{llll} 
& Plant height/cm & & \\
Treatments & $-\mathrm{cm}$ & April 25 & 19 \\
\hline $\mathrm{M}_{0} \mathrm{D}_{0}$ & March 12 & $122.75 \mathrm{a}$ & $199.0 \mathrm{a}$ \\
$\mathrm{M}_{0} \mathrm{D}_{2.5}$ & $90.0 \mathrm{a}$ & $121.25 \mathrm{a}$ & $172.8 \mathrm{a}$ \\
$\mathrm{M}_{0} \mathrm{D}_{5}$ & $86.1 \mathrm{a}$ & $127.5 \mathrm{a}$ & $183.3 \mathrm{a}$ \\
$\mathrm{M}_{15} \mathrm{D}_{0}$ & $92.0 \mathrm{a}$ & $129.25 \mathrm{a}$ & $189.8 \mathrm{a}$ \\
$\mathrm{M}_{15} \mathrm{D}_{2.5}$ & $88.7 \mathrm{a}$ & $129.75 \mathrm{a}$ & $181.0 \mathrm{a}$ \\
$\mathrm{M}_{15} \mathrm{D}_{5}$ & $89.3 \mathrm{a}$ & $116.88 \mathrm{a}$ & $190.0 \mathrm{a}$ \\
$\mathrm{M}_{30} \mathrm{D}_{0}$ & $83.3 \mathrm{ab}$ & $129.25 \mathrm{a}$ & $188.8 \mathrm{a}$ \\
$\mathrm{M}_{30} \mathrm{D}_{2.5}$ & $77.0 \mathrm{~b}$ & $132.50 \mathrm{a}$ & $172.0 \mathrm{a}$ \\
$\mathrm{M}_{30} \mathrm{D}_{5}$ & $84.3 \mathrm{ab}$ & $126.8 \mathrm{a}$ & $201.8 \mathrm{a}$ \\
\hline
\end{tabular}

Table 3: Effects of potassium fulvic acid and DA-6 on the stem fresh and dry weight of tomatoes

\begin{tabular}{|c|c|c|c|c|c|c|}
\hline \multirow[b]{2}{*}{ Treatments } & \multicolumn{3}{|c|}{ Fresh weight of single stem/g } & \multicolumn{3}{|c|}{ Dry weight of single stem/g } \\
\hline & March 12 & April 25 & June1 9 & March 12 & April 25 & June 19 \\
\hline $\mathrm{M}_{0} \mathrm{D}_{0}$ & $90.00 \mathrm{abc}$ & $98.08 \mathrm{c}$ & $232.67 \mathrm{a}$ & $12.25 \mathrm{a}$ & $13.05 \mathrm{a}$ & $30.00 \mathrm{a}$ \\
\hline $\mathrm{M}_{0} \mathrm{D}_{2.5}$ & $83.08 b c$ & $110.08 b c$ & $190.67 \mathrm{a}$ & $11.85 \mathrm{a}$ & $15.38 \mathrm{a}$ & $30.17 \mathrm{a}$ \\
\hline $\mathrm{M}_{0} \mathrm{D}_{5}$ & $85.67 b c$ & $104.75 \mathrm{c}$ & $208.33 a$ & $13.33 \mathrm{a}$ & $14.37 \mathrm{a}$ & $34.70 \mathrm{a}$ \\
\hline $\mathrm{M}_{15} \mathrm{D}_{0}$ & $92.75 \mathrm{ab}$ & $125.42 \mathrm{ab}$ & $232.67 \mathrm{a}$ & $12.00 \mathrm{a}$ & $15.42 \mathrm{a}$ & $34.95 \mathrm{a}$ \\
\hline $\mathrm{M}_{15} \mathrm{D}_{2.5}$ & $91.5 \mathrm{abc}$ & $110.00 \mathrm{bc}$ & $233.00 \mathrm{a}$ & $11.75 \mathrm{a}$ & $13.42 \mathrm{a}$ & $37.32 \mathrm{a}$ \\
\hline $\mathrm{M}_{15} \mathrm{D}_{5}$ & $85.83 b c$ & $103.33 c$ & $224.33 \mathrm{a}$ & $12.00 \mathrm{a}$ & $14.38 \mathrm{a}$ & $35.48 \mathrm{a}$ \\
\hline $\mathrm{M}_{30} \mathrm{D}_{0}$ & $84.35 b c$ & $113.00 \mathrm{bc}$ & $240.00 \mathrm{a}$ & $12.28 \mathrm{a}$ & $15.63 \mathrm{a}$ & $33.25 \mathrm{a}$ \\
\hline $\mathrm{M}_{30} \mathrm{D}_{2.5}$ & $81.58 \mathrm{c}$ & $130.50 \mathrm{a}$ & $221.33 \mathrm{a}$ & $11.75 \mathrm{a}$ & $16.82 \mathrm{a}$ & $41.60 \mathrm{a}$ \\
\hline $\mathrm{M}_{30} \mathrm{D}_{5}$ & $99.58 \mathrm{a}$ & $123.50 \mathrm{ab}$ & $258.33 \mathrm{a}$ & $12.78 \mathrm{a}$ & $16.69 \mathrm{a}$ & $32.66 a$ \\
\hline
\end{tabular}

Table 4: Effects of potassium fulvic acid and DA-6 on the leaf fresh and dry weight of tomato

\begin{tabular}{|c|c|c|c|c|c|c|}
\hline \multirow[b]{2}{*}{ Treatments } & \multicolumn{3}{|c|}{ Fresh weight of leaves per plant/g } & \multicolumn{3}{|c|}{ Dry weight of leaves per plant/g } \\
\hline & March 12 & April 25 & June 19 & March 12 & April 25 & June 19 \\
\hline $\mathrm{M}_{0} \mathrm{D}_{0}$ & $162.17 \mathrm{ab}$ & $174.58 \mathrm{a}$ & $260.33 a$ & $21.00 \mathrm{c}$ & $24.81 \mathrm{c}$ & $33.76 \mathrm{a}$ \\
\hline $\mathrm{M}_{0} \mathrm{D}_{2.5}$ & $159.17 \mathrm{ab}$ & $173.5 \mathrm{a}$ & $246.67 \mathrm{a}$ & $19.17 \mathrm{c}$ & $25.64 \mathrm{abc}$ & $38.33 \mathrm{a}$ \\
\hline $\mathrm{M}_{0} \mathrm{D}_{5}$ & $168.83 \mathrm{ab}$ & $181.42 \mathrm{a}$ & $235.00 \mathrm{a}$ & $22.68 \mathrm{ab}$ & $25.55 b c$ & $37.78 \mathrm{a}$ \\
\hline $\mathrm{M}_{15} \mathrm{D}_{0}$ & $171.08 \mathrm{ab}$ & $193.92 \mathrm{a}$ & $287.00 \mathrm{a}$ & $23.00 \mathrm{ab}$ & $26.57 \mathrm{abc}$ & $37.26 \mathrm{a}$ \\
\hline $\mathrm{M}_{15} \mathrm{D}_{2.5}$ & $185.50 \mathrm{a}$ & $190.00 \mathrm{a}$ & $283.00 \mathrm{a}$ & $23.33 \mathrm{ab}$ & $30.77 \mathrm{ab}$ & $44.35 \mathrm{a}$ \\
\hline $\mathrm{M}_{15} \mathrm{D}_{5}$ & $159.42 \mathrm{ab}$ & $199.17 \mathrm{a}$ & $291.67 \mathrm{a}$ & $24.35 \mathrm{ab}$ & $26.70 \mathrm{abc}$ & $41.91 \mathrm{a}$ \\
\hline $\mathrm{M}_{30} \mathrm{D}_{0}$ & $143.92 b$ & $200.67 \mathrm{a}$ & $251.00 \mathrm{a}$ & $23.68 \mathrm{ab}$ & $28.30 \mathrm{abc}$ & $35.30 \mathrm{a}$ \\
\hline $\mathrm{M}_{30} \mathrm{D}_{2.5}$ & $152.42 b$ & $195.11 \mathrm{a}$ & $337.67 \mathrm{a}$ & $23.93 \mathrm{ab}$ & $30.06 \mathrm{abc}$ & $44.75 \mathrm{a}$ \\
\hline $\mathrm{M}_{30} \mathrm{D}_{5}$ & $186.33 \mathrm{a}$ & $206.00 \mathrm{a}$ & $320.00 \mathrm{a}$ & $25.99 \mathrm{a}$ & $31.206 \mathrm{a}$ & $45.03 \mathrm{a}$ \\
\hline
\end{tabular}

\section{Effect of Potassium Fulvic Acid and DA-6 on Yield per Plant}

It can be seen from Fig. 1A that the addition of DA-6 (treatments $\mathrm{M}_{0} \mathrm{D}_{2.5}$ and $\mathrm{M}_{0} \mathrm{D}_{5}$ ) to nutrient solution alone has little effect on the early-stage yield of tomato. The other combinations can significantly improve the earlystage yield, where $\mathrm{M}_{15} \mathrm{D}_{2.5}$ has the best effect and there is no significant difference with $\mathrm{M}_{20} \mathrm{D}_{2.5}$. As shown in Fig. $1 \mathrm{~B}, \mathrm{M}_{0} \mathrm{D}_{5}, \mathrm{M}_{15} \mathrm{D}_{5}$ and $\mathrm{M}_{15} \mathrm{D}_{2.5}$ were significantly higher than the control and $\mathrm{M}_{15} \mathrm{D}_{2.5}$ had the best effect, significantly higher than other treatments. While the combination of high concentration potassium fulvic acid and DA- $6\left(\mathrm{M}_{30} \mathrm{D}_{5}\right)$ inhibited the medium-term yield. In terms of the output at the later stage of the fruits (Fig. 1C), except for $\mathrm{M}_{0} \mathrm{D}_{5}$ and $\mathrm{M}_{15} \mathrm{D}_{0}$, other treatments were significantly higher than $\mathrm{M}_{0} \mathrm{D}_{0}$, among which $\mathrm{M}_{15} \mathrm{D}_{5}$ had the best effect and there was no significant difference with $\mathrm{M}_{15} \mathrm{D}_{2.5}$ and $\mathrm{M}_{30} \mathrm{D}_{0}$. In view of the total yield (Fig. 1D) and compared with the control, the treatment of $\mathrm{M}_{0} \mathrm{D}_{5}, \mathrm{M}_{15} \mathrm{D}_{0}, \mathrm{M}_{15} \mathrm{D}_{2.5}, \mathrm{M}_{15} \mathrm{D}_{5}$, $\mathrm{M}_{30} \mathrm{D}_{0}$ and $\mathrm{M}_{30} \mathrm{D}_{2.5}$ significantly improved the total yield of tomato per plant. Among them, $\mathrm{M}_{15} \mathrm{D}_{2}$. showed the best performance and increased by $21.77 \%$ compared with the average yield of $M_{0} D_{0}$. The above results show that different combinations have different effects on yield in different fruits periods. Adding potassium fulvic acid $\left(15,30 \mathrm{mg} \cdot \mathrm{L}^{-1}\right)$ alone can significantly increase the early stage yield and adding high concentration potassium fulvic acid $\left(30 \mathrm{mg} \cdot \mathrm{L}^{-1}\right)$ alone can significantly increase the late stage yield. Adding high concentration of DA-6 $\left(5 \mathrm{mg} \cdot \mathrm{L}^{-1}\right)$ alone can significantly increase the mid- 
term stage yield, while adding low concentration of DA-6 $\left(2.5 \mathrm{mg} \cdot \mathrm{L}^{-1}\right)$ alone can significantly increase the late stage yield. The combination of high concentration potassium fulvic acid $\left(30 \mathrm{mg} \cdot \mathrm{L}^{-1}\right)$ and DA-6 can significantly increase the early and late yield. However, the combination of low concentration potassium fulvic acid $\left(15 \mathrm{mg} \cdot \mathrm{L}^{-1}\right)$ and DA-6 significantly promoted the yield in three periods, among which the combination of $15 \mathrm{mg} \cdot \mathrm{L}^{-1}$ potassium fulvic acid and $2.5 \mathrm{mg} \cdot \mathrm{L}^{-1} \mathrm{DA}-6$ had the best effect.

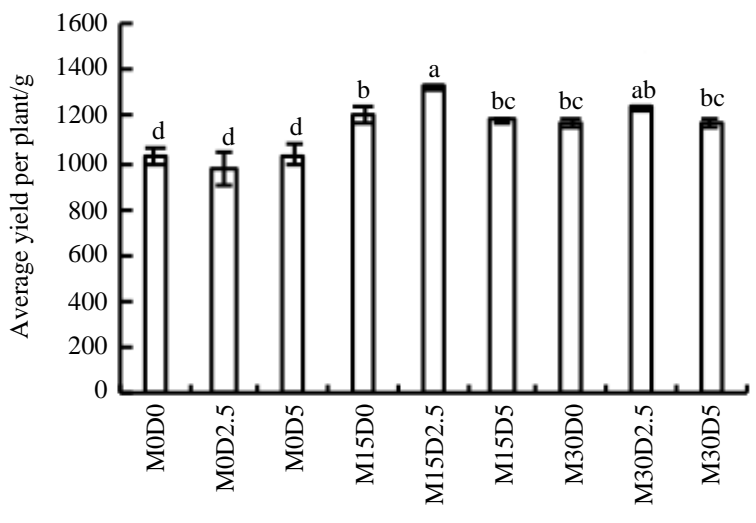

Treatments

(A)

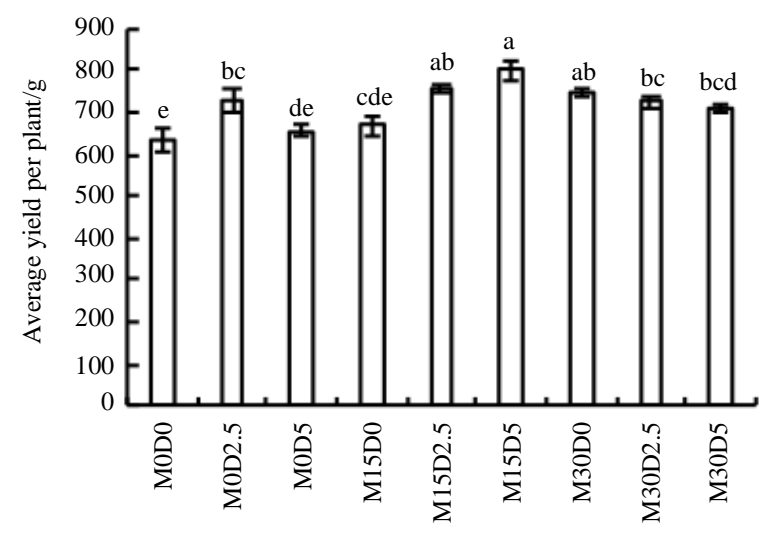

Treatments

(C)

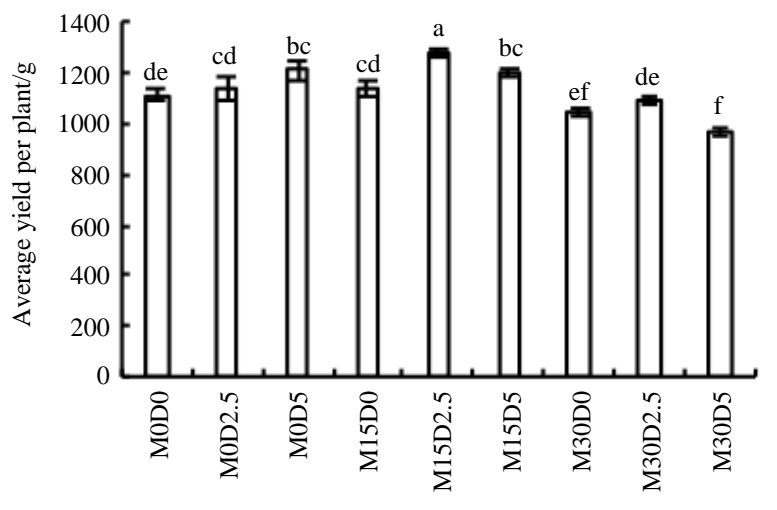

Treatments

(B)

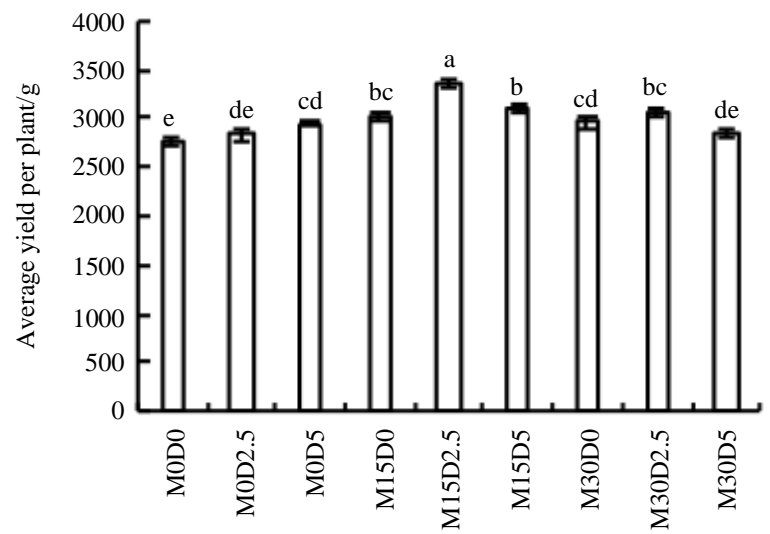

Treatments

(D)

Fig. 1: Effects of potassium fulvic acid and DA-6 on the average yield per plant; (a) Average yield per plant in the early stage; (B) Average yield per plant in the medium stage; (C) Average yield per plant in the late stage; (D) average total yield per plant

Table 5: Effects of potassium fulvic acid and DA-6 on the fruit quality of tomatoes

\begin{tabular}{lllll}
\hline Treatment & Soluble sugar/\% & Vitamin C/(mg. $\left.100 \mathrm{~g}^{-1}\right)$ & Organic acid/\% & Sugar acid ratio \\
\hline $\mathrm{M}_{0} \mathrm{D}_{0}$ & $11.34 \mathrm{ab}$ & $16.72 \mathrm{c}$ & $0.29 \mathrm{~cd}$ & $36.61 \mathrm{~cd}$ \\
$\mathrm{M}_{0} \mathrm{D}_{2.5}$ & $11.67 \mathrm{ab}$ & $21.74 \mathrm{a}$ & $0.41 \mathrm{a}$ & $29.96 \mathrm{e}$ \\
$\mathrm{M}_{0} \mathrm{D}_{5}$ & $10.38 \mathrm{~b}$ & $16.72 \mathrm{c}$ & $0.37 \mathrm{ab}$ & $27.48 \mathrm{e}$ \\
$\mathrm{M}_{15} \mathrm{D}_{0}$ & $11.33 \mathrm{ab}$ & $20.07 \mathrm{ab}$ & $0.34 \mathrm{bc}$ & $32.5 \mathrm{de}$ \\
$\mathrm{M}_{15} \mathrm{D}_{2.5}$ & $10.96 \mathrm{ab}$ & $19.73 \mathrm{ab}$ & $0.26 \mathrm{~d}$ & $47.05 \mathrm{a}$ \\
$\mathrm{M}_{15} \mathrm{D}_{5}$ & $12.54 \mathrm{a}$ & $21.07 \mathrm{a}$ & $0.31 \mathrm{bcd}$ & $44.38 \mathrm{ab}$ \\
$\mathrm{M}_{30} \mathrm{D}_{0}$ & $12.57 \mathrm{a}$ & $17.06 \mathrm{c}$ & $0.27 \mathrm{~d}$ & $47.37 \mathrm{a}$ \\
$\mathrm{M}_{30} \mathrm{D}_{2.5}$ & $12.01 \mathrm{ab}$ & $18.39 \mathrm{bc}$ & $0.31 \mathrm{bcd}$ & $38.46 \mathrm{bcd}$ \\
$\mathrm{M}_{30} \mathrm{D}_{5}$ & $11.64 \mathrm{ab}$ & $18.06 \mathrm{bc}$ & $0.28 \mathrm{~cd}$ & $41.74 \mathrm{abc}$ \\
\hline
\end{tabular}




\section{Effect of Potassium Fulvic Acid and DA-6 on the Fruit Quality of Tomatoes}

It can be seen from Table 5 that the effect of potassium fulvic acid and DA-6 on the content of soluble sugar is not obvious. The content of vitamin $\mathrm{C}$ in $\mathrm{M}_{0} \mathrm{D}_{2.5}$, $\mathrm{M}_{15} \mathrm{D}_{0}, \mathrm{M}_{15} \mathrm{D}_{2.5}$ and $\mathrm{M}_{15} \mathrm{D}_{5}$ was significantly higher than that $\mathrm{M}_{0} \mathrm{D}_{0}$, which showed that the content of vitamin $\mathrm{C}$ in tomato fruits could be significantly increased by adding low concentration of potassium fulvic acid (15 $\left.\mathrm{mg} \cdot \mathrm{L}^{-1}\right)$ or DA-6 $\left(2.5 \mathrm{mg} \cdot \mathrm{L}^{-1}\right)$, or low concentration of potassium fulvic acid $\left(15 \mathrm{mg} \cdot \mathrm{L}^{-1}\right)$ combined with DA6. The content of titratable acid in $\mathrm{M}_{0} \mathrm{D}_{2.5}$ and $\mathrm{M}_{0} \mathrm{D}_{5}$ was significantly higher than $\mathrm{M}_{0} \mathrm{D}_{0}$. There was no significant difference in other treatments. The sugar acid ratio of $\mathrm{M}_{15} \mathrm{D}_{2.5}, \quad \mathrm{M}_{15} \mathrm{D}_{5}$ and $\mathrm{M}_{30} \mathrm{D}_{0}$ was significantly higher than that of $\mathrm{M}_{0} \mathrm{D}_{0}$, indicating that the sugar acid ratio of fruit could be significantly increased by adding high concentration $\left(30 \mathrm{mg} \cdot \mathrm{L}^{-1}\right.$ ) potassium fulvic acid alone, or low concentration (15 $\mathrm{mg} \cdot \mathrm{L}^{-1}$ ) potassium fulvic acid combined with DA-6. In conclusion, the low concentration of potassium fulvic acid $\left(15 \mathrm{mg} \cdot \mathrm{L}^{-1}\right)$ combined with DA-6 $\left(\mathrm{M}_{15} \mathrm{D}_{2.5}\right.$ and $\mathrm{M}_{15} \mathrm{D}_{5}$ ) can significantly increase the vitamin $\mathrm{C}$ content of tomatoes; the sugar acid ratio of fruits is improved and the quality is increased.

\section{Discussion}

Soilless cultivation is a kind of crop cultivation technology developed in recent years and the core of soilless cultivation is nutrient solution, which is the most important way for plants to obtain nutrients and directly affects plant growth, fruit yield and quality (Signore, 2008; He et al., 2017). In recent years, with the deepening of plant nutrition research, the research on beneficial nutrients, growth regulators and growth stimulants for crop growth, yield, disease resistance, stress resistance and quality improvement has gradually increased (Gao et al., 2017; Ma et al., 2018). Potassium fulvic acid and DA-6 as two plant growth regulators are also widely used. Chen and Ji (2019) added different concentrations of fulvic acid $\left(0,0.25,0.5\right.$ and $\left.1 \mathrm{~g} \cdot \mathrm{L}^{-1}\right)$ to the nutrient solution and found that the plant height, fresh leaf weight and dry weight of lettuce increased first and then decreased with the increase of fulvic acid content, while there was no significant difference between plant height (Chen, 2019). Gaowei et al. (2017) found that the yield and dry matter quality of tomato increased significantly with the increase of potassium fulvic acid application (Gao et al., 2017). The results of Qi et al. (2019) showed that the yield of potato could be significantly increased by spraying DA-6 on the leaves of seedlings. In this study, potassium fulvic acid and DA-
6 were added on the basis of basic nutrient solution. It was found that the addition of two substances alone or in combination had no significant effect on the plant height in the medium and later stage of the result. Different concentrations of potassium fulvic acid and DA-6 had no significant effect on the quality of stem and fresh leaves of tomato plants, but on the quality of stem and dry leaves. The results showed that potassium fulvic acid could improve the water holding capacity of plants and promote the accumulation of dry matter in leaves. Among them, $15 \mathrm{mg} \cdot \mathrm{L}^{-1}$ potassium fulvic acid and 2.5 $\mathrm{mg} \cdot \mathrm{L}^{-1}$ DA-6 had the best effect on increasing plant biomass and fruit yield. These results are consistent. This is consistent with the above researches.

Vitamin $\mathrm{C}$, soluble sugar and titratable acid are important indexes reflecting quality. It was found that the appropriate concentration of potassium fulvic acid or DA-6 could increase the content of vitamin and the ratio of sugar to acid. Among them, $15 \mathrm{mg} \cdot \mathrm{L}^{-1}$ potassium fulvic acid and $2.5 \mathrm{mg} \cdot \mathrm{L}^{-1}$ DA-6 had the best comprehensive effect. It has been found that fulvic acid can complex trace elements, form fulvic acid trace element complex, improving the absorption and transport capacity of plants for trace elements. However, the content of vitamin $\mathrm{C}$ is closely related to some trace elements, thus indirectly increasing the content of vitamin $\mathrm{C}$ (Chen and $\mathrm{Ji}, 2019$ ). However, the sugar increasing effect of potassium fulvic acid or DA-6 is not obvious, which is not consistent with the results of previous studies that DA-6 can improve the sugar content of products (Gao et al., 2017). Chen et al. found that 0.25 and $0.5 \mathrm{~g} \cdot \mathrm{L}^{-1}$ potassium fulvic acid could significantly improve the soluble sugar content of lettuce compared with the potassium fulvic acid. However, the content of $1 \mathrm{~g} \cdot \mathrm{L}^{-1}$ decreased significantly.

\section{Conclusion}

In this study, there was no significant effect on the plant height of tomato in different periods, whether adding potassium fulvic acid alone or combining it with DA-6 to the nutrient solution. In the early stage of bearing fruit, during which the temperature is lower, adding high concentration of potassium fulvic acid (30 $\mathrm{mg} \cdot \mathrm{L}^{-1}$ ) had obvious inhibitory effect on the plant height of tomato and the fresh quality of tomato stem and leaf was not significantly affected. But the accumulation of leaf dry weight was different and significantly higher than that in the control in the early stage of bearing fruit. However the difference was not obvious in the late stage of brearing friut. As for the effect on tomato yield, high concentration of potassium fulvic acid and DA-6 can significantly improve the yield of tomato in the early and late stages of bearing fruit and low concentration of 
potassium fulvic acid and DA-6 can significantly improve the total yield of tomato. In this experiment, the application effect of potassium fulvic acid and DA-6 was verified by adding them to nutrient solutionin in soilless cultivation of tomato and the synergistic effect and optimal concentration ratio were preliminarily identified, which provided reference for the scientific and convenient application of potassium fulvic acid and DA-6 in soilless cultivation. In future, we will study the mechanism of synergistic effect of potassium fulvic acid and DA-6 on the growth, yield and quality of tomato, so as to provide scientific basis for their application in production.

\section{Acknowledgement}

The work is supported by the Special support project for the construction of technology system of Bulk vegetable industry in Henan Province (S2015-03).

\section{Author's Contributions}

Xiao Huaijuan: Conceived and designed the experiments and wrote the paper.

Zhou Yan: Conceived and designed the experiments.

Mao Ke and Liu Ke: Analyzed the data.

Wang Jiqing: Contributed reagents/materials/analysis tools.

All authors read and approved the final manuscript.

\section{Ethics}

The authors declare that there is no ethical issue.

\section{References}

Baigorri, R., M. Fuentes, G. Gonza Lez-Gaitano, J.M. García-Mina and G. Almendros et al., 2009. Complementary multianalytical approach to study the distinctive structural features of the main humic fractions in solution: Gray humic acid, brown humic acid and fulvic acid. J. Agric. Food Chem., 57: 3266-3272. DOI: 10.1021/jf8035353

Canellas, L.P., F.L. Olivares, N.O. Aguiar, D.L. Jones and A. Nebbioso et al., 2015. Humic and fulvic acids as biostimulants in horticulture. Scientia Hortic., 196: 15-27.

DOI: 10.1016/j.scienta.2015.09.013

Chen, X.L., J.J. Zhang, R. Chen, Q.L. Li and Y.S. Yang et al., 2013. An uncommon plant growth regulator, diethyl aminoethyl hexanoate, is highly effective in tissue cultures of the important medicinal plant purple coneflower (Echinacea purpurea L.). BioMed Res. Int., 2013: 540316-540316.

DOI: $10.1155 / 2013 / 540316$
Chen, Z.J. and J.Z. Ji, 2019. Effects of fulvic acid on the growth and quality of Italian lettuce in hydroponic culture. Hunan Agric. Sci., 10: 33-35. DOI: 10.16498/j.cnki.hnnykx.2019.010.009

Chzhu, O.P., D.E. Araviashvili and I.G. Danilova, 2020. Studying properties of prospective biologically active extracts from marine hydrobionts. Emerg. Sci. J., 4: 37-43. DOI: 10.28991/esj-2020-01208

De Pascale, S., Y. Rouphael and G. Colla, 2017. Plant biostimulants: Innovative tool for enhancing plant nutrition in organic farming. Eur. J. Hortic. Sci., 82: 277-285. DOI: 10.17660/eJHS.2017/82.6.2

Gao, W., M.Y. Li, J. Yang, G. XianBiao and F. HaiJuan et al., 2017. Effects of different application amounts of potassium fulvate on yield and quality of tomato and soil physical and chemical properties. Agric. Sci. Technol., 18: 2392-2395.

He, S.H., D. He, C.L. Xu, L. Zhao and L. Quan et al., 2017. Effects of nutrient solution on growth and quality of short-term cultivation tomatoes grown in rockwool. Trans. Chinese Society Agric. Eng., 33: $188-195$.

DOI: $10.11975 /$ j.issn.1002-6819.2017.18.025

Jiang, L.Q., H.Y. Pei, W.R. Hu, F. Han and L. Zhang et al., 2015. Effect of diethyl aminoethyl hexanoate on the accumulation of high-value biocompounds produced by two novel isolated microalgae. Bioresource Technol., 197: 178-184.

DOI: 10.1016/j.biortech.2015.08.068

Justi, M., E.G. Morais and C.A. Silva, 2019. Fulvic acid in foliar spray is more effective than humic acid via soil in improving coffee seedlings growth. Arch. Agronomy Soil Sci., 65: 1969-1983.

DOI: $10.1080 / 03650340.2019 .1584396$

Li, H.S., Q. Sun and S.J. Zhao, 2000. The Experiment Principle and Technique on Plant Physiology and Biochemistry. 1st Edn., Higher Education Press, Beijing, pp: 261.

Li, Z.W., R.S. Zhang and H.M. Zhang, 2018. Effects of plant growth regulators (DA-6 and 6-BA) and EDDS chelator on phytoextraction and detoxification of cadmium by Amaranthus hybridus Linn. Int. J. Phytoremediat., 20: 1121-1128.

DOI: $10.1080 / 15226514.2017 .1365348$

Liu, J.H., Q. Wang and R.J. Luo, 2019. Effect of fulvic acid fertilizer on microbial diversity and enzyme activity in wheat rhizosphere soil. J. Plant Nutrit. Fertilizers, 25: 1808-1816.

Ma, C.X., H.J. Xiao, J.Q. Li, J. Wang and K. Liu et al., 2018. Effect of foliar-sprayed fermented japamese hop (Humulus scandens merr.) juice on the growth and yield of lettuce. Bangladesh J. Botany, 47: 573-579. 
Moayedi, A., B. Yargholi, E. Pazira and H. Babazadeh, 2019. Investigated of desalination of saline Waters by using dunaliella salina algae and its effect on water ions. Civil Eng. J., 5: 2450-2460.

DOI: 10.28991/cej-2019-03091423

Nkansah, M.A., M. Shamsu-Deen and F. Opoku, 2018. Phytocompounds, heavy metal and mineral contents in honey samples from selected markets in the kumasi metropolis. Emerg. Sci. J., 2: 287-294. DOI: 10.28991/esj-2018-01152

Qi, D.Q., J.J. Zhao and N.J. Feng, 2019. Effects of S3307 and DTA-6 on sugar metabolism and yield of potato leaves and tubers. Crops, 4: 148-153.

Salama, E.S., B.H. Jeon, S.W. Chang, S.H. Lee and H.S. Roh et al., 2017. Interactive effect of indole-3-acetic acid and diethyl Aminoethyl hexanoate on the growth and fatty acid content of some microalgae for biodiesel production. J. Cleaner Product., 68: 1017-1024. DOI: 10.1016/j.jclepro.2017.09.057
Signore, A., 2008. Influence of salinity source on production, quality and environmental impact of tomato grown in a soilless closed system. J. Food Agric. Environ., 6: 357-361.

Stevenson, F.J., 1994. Humus Chemistry. 1st Edn., John Wiley and Sons, New York, pp: 512.

Xiao, Y., Y.P. Cao, J.G. Wang, J.G. Wang and K. Chen, 2004. Research of mixed adjuvants on the absorption of nutrient elements in crop leaf. Plant Nutrit. Fertilizer Sci., 10: 281-285.

Xu, H.L., L. Gauthier and A. Gosselin, 1995. Effects of fertigation management on growth and photosynthesis of tomato plants grown in peat, rockwool and NFT. Scientia Hortic., 63: 11-20. DOI: 10.1016/0304-4238(95)00791-q

Zhang, Q., L. Zhang, J. Evers, W. van der Werf and W. Zhang et al., 2014. Maize yield and quality in response to plant density and application of a novel plant growth regulator. Field Crops Res., 164: 82-89. DOI: $10.1016 /$ j.fcr.2014.06.006 